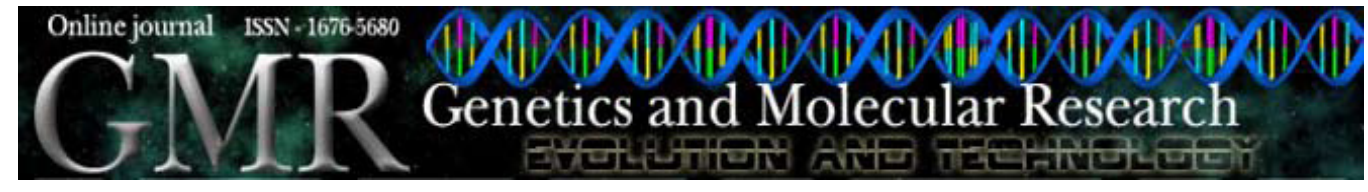

\title{
Epidemiological and molecular study of Ehrlichia canis in dogs in Bahia, Brazil
}

\author{
F.S. Carvalho ${ }^{1}$, A.A. Wenceslau ${ }^{2}$, R.S.A. Carlos $^{3}$ and G.R. Albuquerque ${ }^{2}$ \\ 1Programa de Pós-Graduação em Ciência Animal, \\ Universidade Estadual de Santa Cruz, Ilhéus, BA, Brasil \\ ${ }^{2}$ Departamento de Ciências Agrárias e Ambientais, \\ Universidade Estadual de Santa Cruz, Ilhéus, BA, Brasil \\ ${ }^{3}$ Programa de Pós-Graduação em Ciências Veterinárias, \\ Universidade Federal Rural do Rio de Janeiro, Seropédica, RJ, Brasil \\ Corresponding author: G.R. Albuquerque \\ E-mail: gralbu@uesc.br
}

Genet. Mol. Res. 7 (3): 657-662 (2008)

Received April 7, 2008

Accepted June 24, 2008

Published July 29, 2008

\begin{abstract}
The objective of the present article was an epidemiological and molecular study of Ehrlichia canis in dogs of Ilhéus and Itabuna in Bahia, as well as an evaluation of associated risk factors. Blood samples were collected from 153 dogs and DNA was extracted and analyzed by the nested-polymerase chain reaction, using one pair of primers to detect Ehrlichia bacteria and another pair to detect the presence of $E$. canis. Of the 153 animals, $12(7.8 \%)$ were polymerase chain reaction-positive for E. canis, indicating the presence of the parasite in dogs of the Ilhéus-Itabuna microregion. The associated risk factors were exposure to tick-infested habitats and the fact that the dogs lived in the countryside.
\end{abstract}

Key words: Molecular; Ehrlichiosis; Dogs; Ticks; Rickettsia 


\section{INTRODUCTION}

Ehrlichia is a Rickettsia of the Anaplasmataceae family, Gram-negative intracytoplasmic bacteria, that invade and multiply within leukocytes and platelets in the peripheral blood of various species of domestic and wild mammals. It causes ehrlichiosis (Borjesson, 2000; Mavromatis et al., 2006), a world-wide distributed zoonosis (Perez et al., 2005), concentrated in tropical and subtropical regions due to the geographical distribution of its vector tick Ixodidae Rhipicephalus sanguineus (Andereg and Passos, 1999). It can also infect humans (DantasTorres et al., 2006). In Brazil, this seems to be the main vector for Ehrlichia canis in urban areas, although in rural areas human infection seems to be related to the genus Amblyomma (Labruna and Pereira, 2001).

Several species of Ehrlichia infect dogs such as Anaplasma platys, E. equi, E. ewingii, E. risticii, E. chaffeensis, E. sennetsu, and E. canis. The latter being the main species that infects dogs producing several clinical symptoms (Stiles, 2000) - fever, anorexia, vomiting, loss of weight, enlargement of the liver, spleen and lymph nodes, epistaxis, hemorrhage and thrombocytopenia (Moreira et al., 2003).

Specific diagnosis of ehrlichiosis can be made using a blood smear, indirect immunofluorescence assay, ELISA, Western blot, and polymerase chain reaction (PCR) (Cadman et al., 1994; Iqbal et al., 1994; Hegarty et al., 1997; Carlos et al., 2007).

PCR is a technique used in the early diagnosis of ehrlichiosis and also for identification of the infecting species, helping with the taxonomic schemes (Iqbal et al., 1994). Using PCR, it is possible to isolate DNA and identify E. canis from blood samples or tissue from lungs, spleen, lymph nodes, kidneys, brain, and eyes of infected animals (Stiles, 2000).

Molecular diagnosis is based on the analyses of the 16S rRNA gene sequence, which is genetically related to Gram-negative intracellular bacteria (Dagnone et al., 2001), as Ehrlichia differs genetically from other Rickettsias (Chen et al., 1994).

The 16S rRNA gene of E. canis was partially sequenced in August 1996, revealing $1433 \mathrm{bp}$. The sequencing was finished in 2007 and has been described and deposited in GenBank under accession number CP000107 (Copeland et al., 2007). The complete genome sequence reveals that $E$. canis has a single circular chromosome of $1,315,030 \mathrm{bp}$ to code for 925 proteins, which can be associated with pathogen-host interactions (Mavromatis et al., 2006).

The prevalence of E. canis, based on the PCR technique, was reported as follows: $21 \%$ in Paraná (Dagnone et al., 2003), 30.9\% in São Paulo (Bulla et al., 2004) and 15\% in Rio de Janeiro (Macieira et al., 2005).

The objective of the present article was an epidemiological and molecular study of Ehrlichia canis in dogs of Ilhéus and Itabuna, in Bahia, Brazil, as well as an evaluation of associated risk factors.

\section{MATERIAL AND METHODS}

\section{Study location}

This comparative study was conducted on the municipalities of Ilhéus (latitude and longitude $14^{\circ} 47^{\prime} 20^{\prime \prime} \mathrm{S}, 39^{\circ} 02^{\prime} 58^{\prime} \mathrm{W}$ ) and Itabuna (latitude and longitude $14^{\circ} 47^{\prime} 08^{\prime \prime} \mathrm{S}$, $39^{\circ} 16^{\prime} 49^{\prime}$ W), the Ilhéus-Itabuna microregion, in the south of Bahia State. The two munici- 
palities have a population of approximately 200,000 inhabitants each and they are $37 \mathrm{~km}$ apart. The climate is warm and humid; the average temperature is $24^{\circ} \mathrm{C}$, and the average annual precipitation is $2134 \mathrm{~mm}$.

\section{Sample collection}

A total of 153 convenience samples were obtained from the Veterinary Outpatient Clinic at the State University of Santa Cruz (UESC), and from veterinary clinics and home visits in both municipalities.

The animals were evaluated and examined and $3 \mathrm{~mL}$ whole blood was collected in tubes with EDTA. The blood samples were identified and kept in isothermal boxes until they could be processed at the Animal Genetics Veterinary Laboratory of UESC.

The analysis of samples was performed using the Epi-Info 6.4 (Dean and Arner, 2007) based on the population of dogs, which was estimated from the human population of the municipalities. To calculate the proportion $\mathrm{dog} /$ human we used the 1:10 ratio, which resulted in a total of 40,000 animals. The sample analysis was carried out considering a $95 \%$ degree of confidence, the possibility of illness detection considered for $15 \%$ of the dogs (Macieira et al., 2005), and a statistical error of 5.65\%, resulting in a sample of 153 dogs.

\section{DNA extraction}

The genomic DNA of the samples was extracted and isolated from $100 \mu \mathrm{L}$ of the dog's whole blood using the extraction kit - ChargeSwitch ${ }^{\circledR}$ gDNA $100 \mu$ L Blood Kits (Invitrogen ${ }^{\circledR}$ ), according to manufacturer instructions, which made it possible to extract small amounts of DNA rapidly and free from contamination. The samples were stored in a freezer at $-20^{\circ} \mathrm{C}$ for later PCR.

\section{Nested-polymerase chain reaction}

The forward primer ECC 5'-AGAACGAACGCTGGCGGCAAGC-3' and the reverse one, ECB 5'-CGTATTACCGCGGCTGCTGGCA-3' were used to amplify part of the 16S rRNA gene of Ehrlichia spp. Afterwards, the samples were subjected to the forward primer 5'-CAATTATTTATAGCCTCTGGCTATAGGA-3' and the reverse one, HE3 5'-TATAGGTACCGTCATTATCTTCCCTAT-3' (Murphy et al., 1998), specific for E. canis.

For the PCR mixture, $6 \mu \mathrm{L}$ purified DNA was used, $0.2 \mathrm{mM}$ of each dNTP, $1.5 \mathrm{mM}$ $\mathrm{MgCl}_{2}, 50 \mathrm{mM} \mathrm{KCl}, 10 \mathrm{mM}$ Tris-HCl, $\mathrm{pH} 9.0,0.2 \mu \mathrm{M}$ of each primer, and $2 \mathrm{U}$ Taq DNA polymerase $\left(\right.$ Invitrogen ${ }^{\circledR}$ ) for a total volume of $25 \mu \mathrm{L}$ reaction mixture. The amplification program used to id entify the genetic sequence of the genus Ehrlichia spp consisted of a first step of denaturation for $3 \mathrm{~min}$ at $94^{\circ} \mathrm{C}$, followed by 35 cycles of denaturation at $94^{\circ} \mathrm{C}$ for $1 \mathrm{~min}$, annealing at $68^{\circ} \mathrm{C}$ for $2 \mathrm{~min}$ and extension at $72^{\circ} \mathrm{C}$ for $2 \mathrm{~min}$. The nested-PCR for the identification of the genetic sequence specific for $E$. canis consisted of denaturation for $3 \mathrm{~min}$ at $94^{\circ} \mathrm{C}$, followed by 35 denaturation cycles at $94^{\circ} \mathrm{C}$ for $1 \mathrm{~min}$, annealing at $58^{\circ} \mathrm{C}$ for $2 \mathrm{~min}$ and extension at $72^{\circ} \mathrm{C}$ for $1.5 \mathrm{~min}$. The PCR products were analyzed using $1.5 \%$ agarose gel electrophoresis, stained with ethidium bromide and photographed. 


\section{Statistical analysis}

The analysis was performed according to the following variables: prevalence between the two municipalities of Ilhéus and Itabuna, gender of the animals (male and female), age group (from 0 to 3 years old, from 4 to 7 years old and over 7 years old), breed (groups of defined and non-defined breed), presence of ticks and animals' location (urban or rural).

The statistical analysis was performed by the chi-square test and the Fisher exact test to determine the relation between the observed variables and the dispersion of these frequencies.

\section{RESULTS AND DISCUSSION}

A total of 153 dogs were evaluated, 84 from Ilhéus and 69 from Itabuna, and among them, 12 animals (7.8\%) were positive for E. canis, 9 animals (10.7\%) in Ilhéus and 3 animals $(4.3 \%)$ in Itabuna. The amplification of the $16 \mathrm{~S}$ rRNA fragment with specific primers for $E$. canis produced a specific, visible, single band pattern of approximately $400 \mathrm{bp}$ (Figure 1).

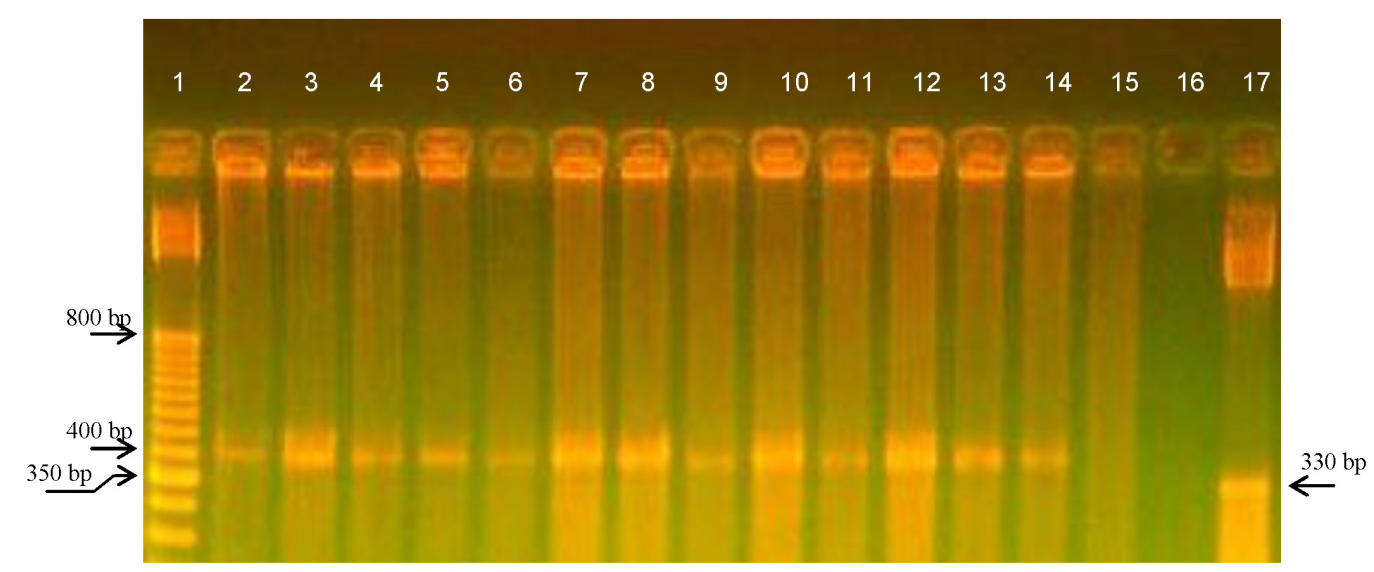

Figure 1. Resolution on agarose gel of the products from nested-polymerase chain reaction with specific primers for Ehrlichia canis. Lane $1=$ molecular weight, 50-bp DNA ladder; lane $2=$ positive control; lanes 3 to $14=$ positive animals; lane 15 = negative animal; lane 16 = negative control; lane $17=$ molecular weight, 10-bp DNA ladder.

The results of this study showed the presence of E. canis in dogs in the microregion of Ilhéus-Itabuna, reporting lower prevalence than in other parts of the country with similar climatic conditions such as Rio de Janeiro (Macieira et al., 2005). This may be due to the lower regional incidence of the disease, which did not seem to be the case, and/or the presence of different species of Ehrlichia, such as E. chaffeensis and E. ewingii, which were not included in the study because of the specificity of the primers used.

There was no significant difference in prevalence $(\mathrm{P}=0.24)$ between the two municipalities, although the number of positive animals in Ilhéus was higher than in Itabuna. This may be explained by the fact that there is a rural neighborhood in Ilhéus, where some samples 
were obtained, and a slight difference (Table 1) was observed between rural and urban dogs, confirming the results reported by Dagnone et al. (2002) who found rural dogs with more positivity for parasites than urban dogs. In this rural area, the population is predominantly poor, and their animals are usually infested with ticks. One must also consider that this site is close to the Atlantic Forest, possibly a reservoir for the wild type of the disease, which could contribute to a higher incidence of the parasite.

\begin{tabular}{|c|c|c|c|c|c|c|}
\hline \multirow[t]{2}{*}{ Location } & \multicolumn{2}{|c|}{ Dogs } & \multirow[t]{2}{*}{$\chi^{2}$} & \multirow[t]{2}{*}{$P$} & \multirow[t]{2}{*}{ Incidence rate $(\mathrm{OR})$} & \multirow[t]{2}{*}{ 95\% Confidence interval } \\
\hline & PCR-positive & PCR-negative & & & & \\
\hline Rural area & 5 & 17 & 5.65 & $0.017^{\mathrm{a}}$ & 5.21 & $1.26-21.29$ \\
\hline Urban area & 7 & 124 & & & & \\
\hline
\end{tabular}

${ }^{\mathrm{a}}$ Chi-square test.

The presence of ticks in dogs was considered to be a risk factor (Table 2), confirming the importance of ticks as a vector for the infection (Groves et al., 1975; Dagnone et al., 2003).

\begin{tabular}{|c|c|c|c|c|c|c|}
\hline \multirow[t]{2}{*}{ Variables } & \multicolumn{2}{|c|}{ Dogs } & \multirow[t]{2}{*}{$\chi^{2}$} & \multirow[t]{2}{*}{$\mathrm{P}$} & \multirow[t]{2}{*}{ Incidence rate (OR) } & \multirow[t]{2}{*}{$95 \%$ Confidence interval } \\
\hline & PCR-positive & PCR-negative & & & & \\
\hline No ticks & 3 & 80 & 3.30 & $0.069^{\mathrm{a}}$ & 3.90 & $0.92-23.34$ \\
\hline With ticks & 9 & 61 & & $0.034^{\mathrm{b}}$ & & \\
\hline Male & 7 & 83 & 0.07 & $0.787^{\mathrm{a}}$ & 1.02 & $0.24-3.95$ \\
\hline Female & 5 & 58 & & $0.599^{\mathrm{b}}$ & & \\
\hline Definite breed & 6 & 99 & 1.26 & $0.260^{\mathrm{a}}$ & 2.36 & $0.59-9.32$ \\
\hline No definite breed & 6 & 42 & & $0.131^{\mathrm{b}}$ & & \\
\hline
\end{tabular}

${ }^{\mathrm{a} C h i-s q u a r e}$ test; ${ }^{\mathrm{b}}$ Fisher exact test.

Analyzing variables, such as sex, breed and age group, no significant differences were reported $(\mathrm{P}>0.26, \mathrm{P}>0.78$ and $\mathrm{P}>0.41$, respectively). These results corroborate those of Borba et al. (2002) in Pernambuco, Dagnone et al. (2002) in Paraná, Inokuma et al. (1999) in Japan, and Cocco et al. (2003) in Italy.

Using the PCR technique, it was possible to detect E. canis in dogs in Ilhéus and Itabuna with a prevalence of $7.8 \%$. However, further research must be carried out using other primers in order to detect other species of the genus Ehrlichia in the region.

\section{ACKNOWLEDGMENTS}

Research supported by FAPESB and UESC.

\section{REFERENCES}

Andereg PI and Passos LMF (1999). Erliquiose canina - Revisão. Clin. Vet. 19: 31-39.

Borba MAC, Mello VSP, Alves LC, Mckee W, et al. (2002). Diagnóstico Sorológico da Erlichiose Canina no Município do 
Cabo de Santo Agostinho, Estado de Pernambuco. XII Congresso Brasileiro de Parasitologia Veterinária, Rio de Janeiro. Borjesson D (2000). Ehrlichiosis: New Perspectives on Pathogenesis and Diagnosis. Proceedings of the 18th ACVIM, Seattle.

Bulla C, Kiomi TR, Pessoa AJ Jr, AparecidaTrinca L, et al. (2004). The relationship between the degree of thrombocytopenia and infection with Ehrlichia canis in an endemic area. Vet. Res. 35: 141-146.

Cadman HF, Kelly PJ, Matthewman LA, Zhou R, et al. (1994). Comparison of the dot-blot enzyme linked immunoassay with immunofluorescence for detecting antibodies to Ehrlichia canis. Vet. Rec. 135: 362.

Carlos RSA, Muniz Neta ES, Spagnol FH, Oliveira LLS, et al. (2007). Freqüência de anticorpos anti-Erhlichia canis, Borrelia burgdorferi e antígenos de Dirofilaria immitis em cães na microrregião Ilhéus-Itabuna, Bahia, Brasil. Rev. Bras. Parasitol. Vet. 16: 117-120.

Chen SM, Dumler JS, Bakken JS and Walker DH (1994). Identification of a granulocytotropic Ehrlichia species as the etiologic agent of human disease. J. Clin. Microbiol. 32: 589-595.

Cocco R, Sanna G, Cillara MG, Tola S, et al. (2003). Ehrlichiosis and rickettsiosis in a canine population of Northern Sardinia. Ann. N. Y. Acad. Sci. 990: 126-130.

Copeland A, Lucas S, Lapidus A, Barry K, et al. (2007). Complete sequence of Ehrlichia canis str. Jake. http://www.ncbi. nlm.nih.gov/entrez/viewer.fcgi?db=nucleotide\&val=72393774. Accessed November 14, 2007.

Dagnone AS, Morais HSA and Vidotto O (2001). Erliquiose nos animais e no homem. Sem. Cienc. Agrar. 2: 191-209.

Dagnone AS, Trapp SM, Jojima FS, Amude AM, et al. (2002). Avaliação Soroepidemiológica da Infecção por Ehrlichia canis, Dirofilaria immitis e Borrelia burgdorferi em Cães de uma População Hospitalar. XII Congresso Brasileiro de Parasitologia Veterinária, Rio de Janeiro.

Dagnone AS, de Morais HS, Vidotto MC, Jojima FS, et al. (2003). Ehrlichiosis in anemic, thrombocytopenic, or tickinfested dogs from a hospital population in South Brazil. Vet. Parasitol. 117: 285-290.

Dantas-Torres F, Figueredo LA and Brandao-Filho SP (2006). Rhipicephalus sanguineus (Acari: Ixodidae), the brown dog tick, parasitizing humans in Brazil. Rev. Soc. Bras. Med. Trop. 39: 64-67.

Dean AG and Arner T (2007). Epi-Info: Epidemiology of program office. http://www.cdc.gov/epiinfo/. Accessed October 30, 2007.

Groves MG, Dennis GL, Amyx HL and Huxsoll DL (1975). Transmission of Ehrlichia canis to dogs by ticks (Rhipicephalus sanguineus). Am. J. Vet. Res. 36: 937-940.

Hegarty BC, Levy MG, Gager RF and Breitschwerdt EB (1997). Immunoblot analysis of the immunoglobulin G response to Ehrlichia canis in dogs: an international survey. J. Vet. Diagn. Invest. 9: 32-38.

Inokuma H, Ohno K and Yamamoto S (1999). Serosurvey of Ehrlichia canis and Hepatozoon canis infection in dogs in Yamaguchi Prefecture, Japan. J. Vet. Med. Sci. 61: 1153-1155.

Iqbal Z, Chaichanasiriwithaya W and Rikihisa Y (1994). Comparison of PCR with other tests for early diagnosis of canine ehrlichiosis. J. Clin. Microbiol. 32: 1658-1662.

Labruna MB and Pereira MC (2001). Carrapato em cães no Brasil. Clin. Vet. 30: 24-32.

Macieira DB, Messik JB, Cerqueira AM, Freire IMA, et al. (2005). Prevalence of Ehrlichia canis infection in thrombocytopenic dogs from Rio de Janeiro, Brazil. Vet. Clin. Pathol. 34: 44-48.

Mavromatis K, Doyle CK, Lykidis A, Ivanova N, et al. (2006). The genome of the obligately intracellular bacterium Ehrlichia canis reveals themes of complex membrane structure and immune evasion strategies. J. Bacteriol. 188: 4015-4023.

Moreira SM, Bastos CV, Araújo RB, Santos M, et al. (2003). Retrospective study (1998-2001) on canine ehrlichiosis in Belo Horizonte, MG, Brazil. Arq. Bras. Med. Vet. Zootec. 55: 141-147.

Murphy GL, Ewing SA, Whitworth LC, Fox JC, et al. (1998). A molecular and serologic survey of Ehrlichia canis, E. chaffeensis, and E. ewingii in dogs and ticks from Oklahoma. Vet. Parasitol. 79: 325-339.

Perez M, Bodor M, Zhang C and Rikihisa Y (2005). Ehrlichia canis detection in symptomatic humans in Venezuela. In: Proceedings of the Fourth International Conference on Rickettsiae and Rickettsial Diseases, Logrono.

Stiles J (2000). Canine rickettsial infections. Vet. Clin. North Am. Small Anim. Pract. 30: 1135-1149. 